\title{
Bagaza virus is pathogenic and transmitted by direct contact in experimentally infected partridges, but is not infectious in house sparrows and adult mice
}

\author{
Francisco Llorente ${ }^{1}$, Elisa Pérez-Ramírez ${ }^{1}$, Jovita Fernández-Pinero ${ }^{1}$, Maia Elizalde$^{1}$, Jordi Figuerola², \\ Ramón C. Soriguer ${ }^{2}$ and Miguel Ángel Jiménez-Clavero ${ }^{1 *}$
}

\begin{abstract}
Bagaza virus (BAGV) is a mosquito-borne flavivirus belonging to the Ntaya serocomplex. In 2010, a disease outbreak was reported in Cádiz (Southern Spain) affecting game birds (red-legged partridges and common pheasants). In this work, red-legged partridges were inoculated experimentally with infectious BAGV isolated from this outbreak in order to make a complete clinical and analytical assessment of the disease caused by the pathogen in this species. Viral load (by real-time RT-PCR) in blood, oral and cloacal swabs, and feathers, and neutralizing antibody titres (by VNT) were measured. In order to determine direct contact transmission, non-inoculated partridges were caged together with the inoculated ones. To assess infectiousness in other species, house sparrows and mice were also inoculated with the virus. All the inoculated partridges were clinically affected, and 30\% of them died. All the infected individuals lost weight, with larger losses being recorded in females. Conversely, no mortality or disease symptoms were observed in the sparrows or mice. Remarkably, all the contact partridges acquired the infection by direct (non-vectored) transmission. This study confirms that the red-legged partridge is a susceptible host for BAGV infection, and that this pathogen is transmitted by direct contact. Long-lasting viral loads detected in calami of immature feathers demonstrate that feather sampling could be a useful strategy in active surveillance programs for early detection of BAGV.
\end{abstract}

\section{Introduction}

The incidence and geographical distribution of mosquitoborne epornitic flaviviruses have increased in the last decade in different parts of the world [1]. Europe and the Mediterranean Basin constitute good examples of the recent introduction and geographical spread of these types of flaviviruses, which are of concern for both animal and human health, e.g. West Nile and Usutu viruses [1-4]. Likewise, other flaviviruses have also appeared recently beyond their known geographic ranges. This is the case of Bagaza Virus (BAGV), belonging to the Ntaya serocomplex, in Southern Spain in September 2010, associated

\footnotetext{
* Correspondence: majimenez@inia.es

'Centro de Investigación en Sanidad Animal, Instituto Nacional de Investigación y Tecnología Agraria y Alimentaria (INIA-CISA), Ctra Algete-El Casar s/n, Valdeolmos, Spain

Full list of author information is available at the end of the article
}

with an unusually high mortality of red-legged partridges (Alectoris rufa) and ring-necked pheasants (Phasianus colchicus) [5]. This outbreak was the first one of BAGV detected in Europe, and enabled its first isolation from a vertebrate host. Although no clinical disease has been reported since the outbreak in 2010, specific Bagaza virus-neutralizing antibodies were detected in 2011-2012 in shot birds from both species in the same region, including juvenile partridges suggesting continued circulation of the virus [6].

BAGV was first isolated in the Central African Republic in 1966, from a pool of Culex mosquitoes [7]. Subsequently, it was detected in mosquitoes in other countries in Western Africa [8-10] and India [11]. A comparison of full-length sequences indicates that BAGV and Israel turkey meningoencephalomyelitis virus (ITV), a pathogen affecting turkeys reported in Israel and South 
Africa, are the same virus species, and the name Avian meningoencephalomyelitis virus (AMEV) was proposed to unify them [12].

Information on the pathogenesis of BAGV has recently been obtained from natural Bagaza infection during the outbreak in Southern Spain in 2010 [13-15]. As regards experimental infections, previous studies have been mainly limited to old ITV and BAGV strains inoculated in domestic turkeys [16] and mice [17], while experimental inoculations of recent BAGV strains are lacking. Therefore, the first aim of this study was to assess if a BAGV isolate from a recent European outbreak is able to reproduce, under experimental conditions, the disease observed in the field in the same bird species from which it was isolated.

Hence, the course of the viremia, seroconversion, viral distribution in organs/tissues and virus shedding through different routes were examined in red-legged partridges in order to gain knowledge about BAGV pathogenicity and tissue tropism in this species, and its role as a reservoir host. Possible contact transmission and the usefulness of different samples for diagnosis were also studied. Moreover, the same BAGV isolate was inoculated in the house sparrow (Passer domesticus) and in mice (Mus musculus) in order to assess its infectiousness and pathogenicity in these species and to further assess the host range for this virus.

\section{Materials and methods}

\section{Virus isolation and preparation of inocula}

The virus used in the inoculations was isolated from the heart of a partridge found dead in the outbreak registered in Southern Spain in 2010 [2]. The original tissue (heart) was homogenized, clarified and inoculated in BSR cells (clone of BHK-21 cell line). After two passages in BSR and four passages in Vero cells, a cytopathic effect was observed in the cell cultures, from which the virus was recovered, grown and titrated by plaque assay in Vero cells as previously described [18]. The isolated virus, named BAGV Spain RLP-Hcc2/2010, was completely sequenced [GenBank:KR108245]).

\section{Birds and mice \\ Red-legged partridges}

Five-month-old red-legged partridges (Alectoris rufa) $(n=30)$ were obtained from the Lugar Nuevo red-legged partridge breeding facility (Estación de Referencia de la Perdiz Roja, Consejería de Medio Ambiente y Ordenación del Territorio-Junta de Andalucía, Andujar, Spain, 38 $16^{\prime}$ $\left.\mathrm{N} 4^{\circ} 6^{\prime} \mathrm{W}\right)$, which guarantees the lack of hybridization with other partridge species. Prior to the experiment, all individuals were tested serologically using a commercially available competitive ELISA (Ingezym West Nile Compac, INGENASA, Madrid, Spain) and virologically (by real-time
RT-PCR as described below) to ensure that previous exposure to BAGV or other flaviviruses had not occurred. The partridges were transported to the biosafety level 3 (BSL-3) facilities at CISA (Centro de Investigación en Sanidad Animal, Valdeolmos, Spain). After careful deparasiting, the birds were distributed in three wire mesh cages $(120 \times 40 \times 40 \mathrm{~cm})$ in experimental groups, (see below this section, under "Experimental inoculation"), composed of $50 \%$ males and $50 \%$ females (estimated considering body size and presence of spur, and confirmed after necropsy at the end of the experiment). The birds were provided with a commercial diet for game birds and water ad libitum throughout the experiment.

\section{House sparrows}

Free-living house sparrows (Passer domesticus) were captured using mist nets and banded in Southern Spain (Seville) and adapted to captivity for two months in outdoor cages. The sparrows were transported to the BSL-3 facilities at CISA, deparasited and housed in individual wire cages $(45 \times 40 \times 30 \mathrm{~cm})$ and tested serologically and virologically to discard previous exposure to flavivirus, as explained above for red-legged partridges. The sparrows were provided with mixed bird food and water ad libitum.

\section{Mice}

Three-week-old Swiss HSD ICR (CD1) outbred female mice were purchased from Harlan Inc. (Switzerland) and kept in the CISA BSL-3 facility until their inoculation at the age of 4 weeks.

Animal care, handling and experimental procedures were authorized by the INIA Committee of Ethics and Animal Experimentation (Reference codes: BV/Pe-1, BV/Go-1 and BV/Mo-1) according to European and Spanish laws on the protection of animals for experimental and other scientific purposes (Spanish Royal Decree 53/2013 and Council Directive 2010/63/EU).

\section{Experimental inoculations}

After 7 days for acclimatization, the birds and mice were inoculated with BAGV (strain Spain RLP-Hcc1/2010) diluted in up to $0.1 \mathrm{~mL}$ in Dulbecco's Minimum Essential Medium (DMEM) (supplemented with $2 \mathrm{mM} \mathrm{L-glutamine,}$ $100 \mathrm{U} / \mathrm{mL}$ penicillin and $100 \mu \mathrm{g} / \mathrm{mL}$ streptomycin).

Distribution of animals in experimental groups: One group composed of 10 red-legged partridges (inoculated group) and another group of 6 birds (programmed necropsy group) were inoculated subcutaneously in the neck with approximately $2 \times 10^{5}$ pfu (plaque-forming units) of BAGV/individual. Both groups were kept in separated cages. A third group, consisted of four non-inoculated partridges (contact group), was kept with the inoculated group, in the same cages. One additional group of partridges 
(control group; $n=10$ ) was sham-inoculated with an equivalent volume of DMEM and kept in a separate cage.

Eight house sparrows were inoculated subcutaneously in the neck with approximately $2 \times 10^{5} \mathrm{pfu} /$ individual of BAGV whereas another group $(n=8)$ was sham-inoculated and used as control. All the sparrows were kept in individual cages.

Four groups, each consisting of two 4-week-old mice were inoculated intraperitoneally with tenfold dilution doses of BAGV ranging from $5 \times 10^{2}$ to $5 \times 10^{5}$ pfu/individual. The control group was composed of two mice that were sham-inoculated and housed in a different cage.

\section{Clinical follow-up and collection of samples Red-legged partridges}

Disease symptoms were observed daily for up to 15 days post-inoculation (dpi) in the inoculated and control groups and for up to $18 \mathrm{dpi}$ in the contact group. To follow the viremia course, blood samples were collected at 1 , $3,5,7,9,11$ and $15 \mathrm{dpi}$ in the inoculated and control groups and at 3, 5, 7, 9, 11, 15 and $18 \mathrm{dpi}$ in the contact group. Blood samples $(0.1 \mathrm{~mL})$ were collected in sterile polypropylene tubes filled with $0.9 \mathrm{~mL}$ BA-1 diluent (Hanks M-199 salts, $0.05 \mathrm{M}$ Tris, $\mathrm{pH}$ 7.6, 1\% bovine serum albumin, $0.35 \mathrm{~g} / \mathrm{L}$ of sodium bicarbonate, 100 units $/ \mathrm{mL}$ of penicillin, $100 \mu \mathrm{g} / \mathrm{mL}$ of streptomycin, $1 \mu \mathrm{g} /$ $\mathrm{mL}$ of amphotericin $\mathrm{B}$ ) and stored at $-70{ }^{\circ} \mathrm{C}$ until analysis. A second blood sample (0.1-0.2 mL/ individual) was taken in dry tubes and allowed to clot at $37^{\circ} \mathrm{C}$ for $1 \mathrm{~h}$, followed by incubation at $4{ }^{\circ} \mathrm{C}$ overnight, to obtain serum. Similarly, immature rump feathers, oropharyngeal and cloacal swabs were collected one day before inoculation, and on the same days post-infection as blood sampling, in all groups.

Swabs were placed in sterile polypropylene tubes containing $1 \mathrm{ml}$ PBS, while feathers were collected in empty sterile polypropylene tubes, and both were stored at $-70{ }^{\circ} \mathrm{C}$ until analysis. Following death, the partridges were necropsied within $<18 \mathrm{~h}$. Individuals from the programmed necropsy group were euthanized humanely by intravenous injection of embutramide (T61 $\bullet$, Intervet - Schering-Plough, Madrid, Spain) on days 4, 7 and $10 \mathrm{dpi}$ (2 birds each day) and subjected to full necropsy. Similarly, survivors from the inoculated and contact groups were euthanized at 15 and 18 dpi respectively. During necropsy, tissue samples (approximately $0.1 \mathrm{~g}$ ) from the brain, heart, kidney, spleen and liver were collected for real-time RT-PCR analysis, using single-use scalpels and forceps to avoid cross-contamination, and placed in tubes containing $0.9 \mathrm{~mL}$ of PBS.

\section{House sparrows}

The house sparrows were monitored daily for up to 14 dpi. Blood samples $(0.1 \mathrm{~mL})$ were collected from the jugular vein at 1, 3, 5, 7, 9 and 15 dpi for viremia determination and at the end of the experiment for antibody detection, as described above for red-legged partridges. The birds were euthanized and necropsied as described previously for partridges.

\section{Mice}

The mice were monitored daily for symptoms for up to 3 weeks after inoculation (when they were euthanized). Blood samples were collected at 3 dpi (for viremia determination) and at $21 \mathrm{dpi}$ for antibody detection in serum.

\section{Viremia, BAGV genome load and complete sequence analyses}

BAGV viremia was measured by standard plaqueformation assays as described [18], while the viral genome load was measured in blood by semiquantitative real-time RT-PCR, using a previously described method [19]. A Ct $=40.0$ was set as cut-off to consider the samples as positives for virus detection by real-time RT-PCR. Tissues, feathers, oropharyngeal and cloacal swabs were examined using the same RNA extraction method and the above described real-time RT-PCR, but following a different preparation step depending on the type of sample. Calami were separated from feathers and placed in tubes containing $0.9 \mathrm{~mL}$ of PBS (one calamus per sampling day and animal). Tissues from necropsies and calami in PBS were homogenized for $2 \mathrm{~min}$ at 30 cycles/s using a Tissuelyser homogenizer (QIAGEN), followed by a centrifugation step at $850 \times g$ $10 \mathrm{~min}$ to clarify homogenates. Swabs were directly clarified at $9500 \mathrm{~g}$ for $5 \mathrm{~min}$. One of the tissue samples with the highest viral genome load (brain from partridge $n^{\circ} 7$ ) was subjected to complete genome sequencing [GenBank:KR108246]).

\section{Antibody detection assays}

Virus-neutralizing antibodies to BAGV in serum were detected and titrated by a virus-neutralization test (VNT) as described [20]. Neutralization titres were assigned based on the highest dilution of each serum capable of neutralizing the infection, i.e. abolishing any observable $\mathrm{CPE}$ in the cell monolayer.

\section{Statistical analysis}

Comparisons of survival rates between inoculated and control groups were carried out using the Gehan-BreslowWilcoxon method [21]. Weight loss (\% initial weight), viremia $(\mathrm{pfu} / \mathrm{mL})$, and genome load (Ct value) data between groups were compared using Student's $t$-test for independent groups for the different sampling days. 


\section{Results}

\section{Pathogenicity and clinical signs}

The BAGV Spain RLP-Hcc2/2010 strain was pathogenic for the red-legged partridge, with an observed mortality of 30\% (3 out of 10 BAGV-inoculated partridges) which occurred between 6 and 10 dpi (Table 1, Figure 1), while no morbidity or mortality was registered in the noninoculated (control) group. However, and considering the limited number of birds by group, differences observed in survival rates between inoculated and control group were not statistically significant $(p>0.05)$. Partridges from the inoculated group showed apathy, reluctance to move, weakness, unresponsiveness and behavioral changes (e.g. lack of avoidance to capture). Some individuals also presented partially closed eyes. From 7 days post infection to the end of the experiment, all inoculated partridges showed a significant body weight loss (between 7 and $23 \%$ of initial weight) as compared to the control group ( $p<0.00001$ from 7 to 15 dpi). Indeed, female partridges suffered a significantly more pronounced and prolonged weight loss than males at $11 \mathrm{dpi}(p=0.004)$ and $15 \mathrm{dpi}(p=0.041)$ (Figure 2).

In the case of inoculated sparrows and mice, no mortality or signs of disease were observed throughout the experiment (Table 1).

\section{Viremia}

Viral genome in blood was detectable in partridges from 1 to 11 dpi (Figure 3). However, viremia (measured by standard plaque-formation) could only be detected at 3 and $5 \mathrm{dpi}$ (Figure 3B). Both viremia titres $\left(1.8 \times 10^{5} \mathrm{pfu} /\right.$ $\mathrm{mL}$ ) and viral genome load peaked at $3 \mathrm{dpi}$. In blood samples with a $\mathrm{Ct}>34$, the virus was not detected by standard plaque formation, which indeed confirms a higher sensitivity of the real time RT-PCR assay used in this study over plaque assay for virus detection in blood.

In the house sparrows, blood samples collected at 1, 3, 5, 7 and $9 \mathrm{dpi}$, were negative for BAGV viral genome assessed by real time RT-PCR, and the same result was

Table 1 Summary of viral inoculations performed in this work

\begin{tabular}{lllll}
\hline Species & $\begin{array}{l}\text { Inoculum } \\
\text { BAGV }\end{array}$ & $\begin{array}{l}\text { Mortality } \\
\text { rate }\end{array}$ & $\begin{array}{l}\text { Mean viral load in } \\
\text { blood 3dpi (Ct) }\end{array}$ & $\begin{array}{l}\text { Ab titre } \\
\text { range }\end{array}$ \\
\hline Partridge & $2 \times 10^{5}$ & $0.3(3 / 10)$ & 23.2 & $320-1280$ \\
House sparrow & $2 \times 10^{5}$ & $0(0 / 8)$ & $>40$ & $<10$ \\
Mouse & $5 \times 10^{2}$ & $0(0 / 2)$ & $>40$ & $<10$ \\
& $5 \times 10^{3}$ & $0(0 / 2)$ & $>40$ & $<10$ \\
& $5 \times 10^{4}$ & $0(0 / 2)$ & $>40$ & $<10$ \\
& $5 \times 10^{5}$ & $0(0 / 2)$ & $>40$ & $10-20$
\end{tabular}

Inoculated doses per individual are indicated as pfu; the mean viral load in blood was measured by real-time RT-PCR at 3 days post-infection (dpi) and the antibody $(\mathrm{Ab})$ titre was determined by virus-neutralization test (VNT) at the end of the experiment.

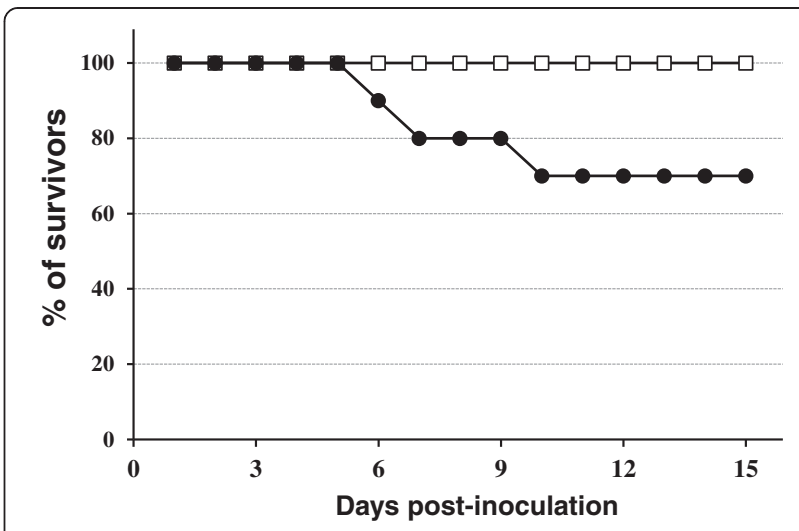

Figure 1 Mortality after inoculation of BAGV in red-legged partridges. Percentage of survivors observed at different days post-inoculation. Closed circles represent BAGV-inoculated partridges. Open squares represent sham-inoculated partridges.

observed in blood samples from mice collected at $3 \mathrm{dpi}$ (Table 1 and data not shown).

\section{Serology}

BAGV-neutralizing antibodies (NtAb) were observed in all partridges surviving the infection. NtAb were first detected at $5 \mathrm{dpi}$ and were observed in all the partridges by $7 \mathrm{dpi}$ with titres ranging from $1: 160$ to $1: 320$ and reaching maximum titres (up to 1:1280) at the end of the experiment (Figure 4 and Table 1). In contrast, NtAb were absent from the blood of the inoculated house sparrows at $15 \mathrm{dpi}$ (Table 1). As for the mice, only those inoculated with the highest dose $\left(5 \times 10^{5} \mathrm{pfu}\right)$ developed

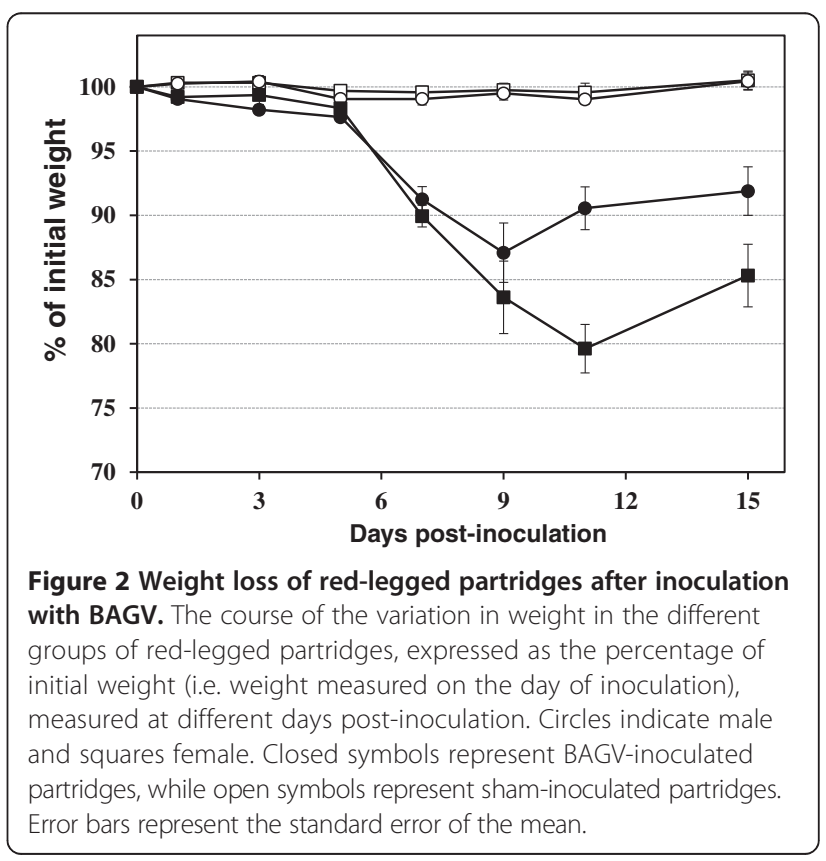



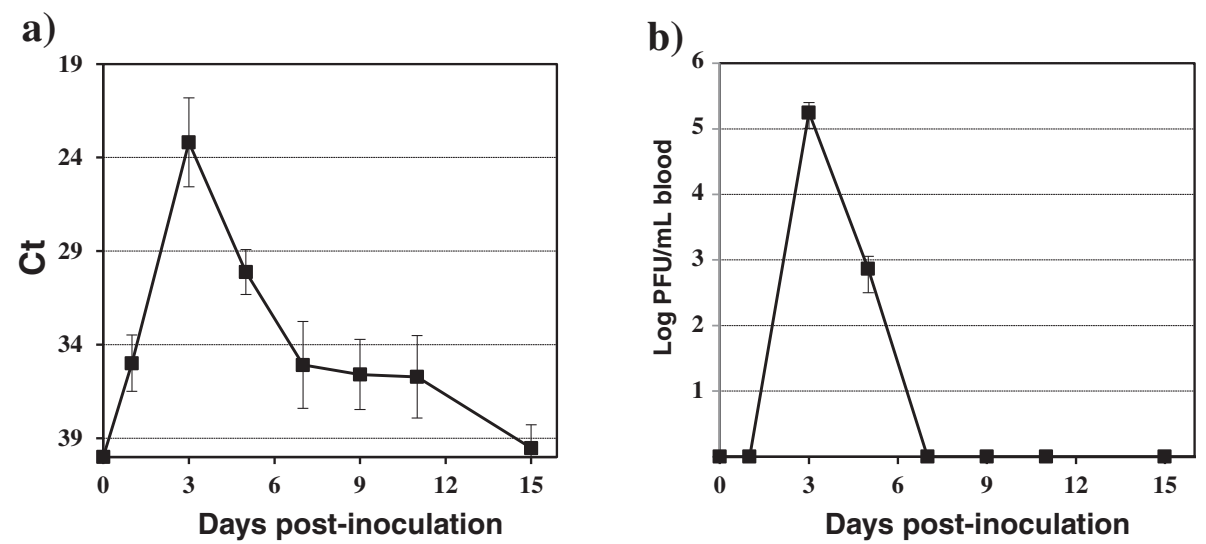

Figure 3 Mean daily blood viral genome load and viremia titres for BAGV-inoculated red-legged partridges. The course of A blood viral genome load and $\mathbf{B}$ viremia titres during the experiment of BAGV inoculation in red-legged partridges, determined at different days post-inoculation. Each point represents the mean obtained for the surviving individuals at different times post-inoculation. Error bars represent the standard error of the mean.

detectable NtAb at $21 \mathrm{dpi}$, showing low titres (1:10 to $1: 20$ ), the rest being negative (titre $<1: 10$ ).

\section{Virus shedding and viral load in feathers}

In the inoculated red-legged partridges, virus shedding was shown to occur from 3 to 11 dpi through the cloacal and oral routes, reaching a maximum at $5 \mathrm{dpi}$, but it was more consistently detected in oropharyngeal than in cloacal swabs (Figure 5).

The viral genome load in feathers reached a peak also at $5 \mathrm{dpi}$, but it was found to be considerably higher and was detectable for a longer period than in blood and in both types of swabs examined. At $15 \mathrm{dpi}$, the virus

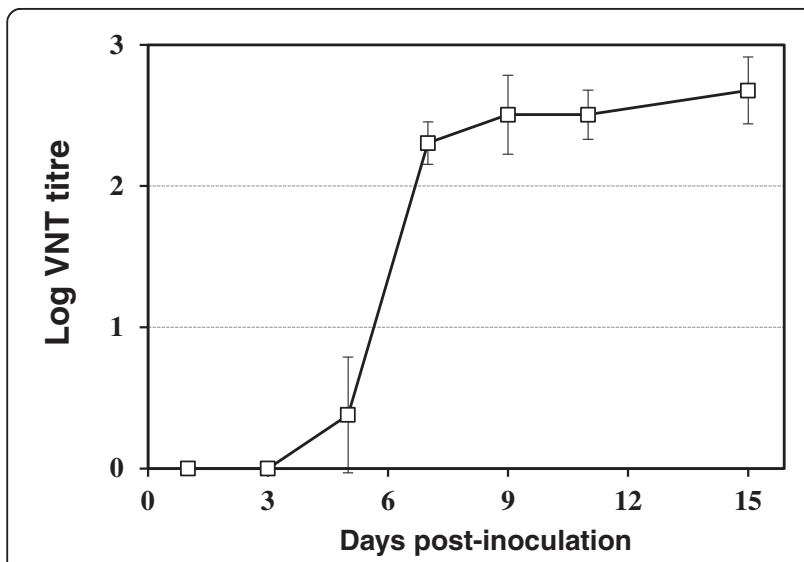

Figure 4 Antibody response to BAGV in serum from BAGVinoculated red-legged partridges. The course of the antibody response in the individuals inoculated with BAGV, measured on different days post-inoculation, is plotted as a solid line with open squares representing the mean log titres of BAGV-neutralizing antibodies measured in the virus-neutralization test (VNT). Error bars represent the standard deviation of the data. genome was still detectable in feathers, while in the swabs, no virus genome was observed beyond $11 \mathrm{dpi}$.

\section{Virus distribution in organs}

The post-mortem examination of the lethally infected red-legged partridges revealed systemic infection, as the virus was detected by real-time RT-PCR in all organs examined, including the brain, heart, spleen, kidney and liver (Table 2). In order to assess the extent of virus distribution in organs at different times post-infection, viral loads were compared in organs collected from BAGV-inoculated birds subjected to programmed necropsies at 4, 7 and $10 \mathrm{dpi}$ and from the birds surviving the infection after $15 \mathrm{dpi}$. While in the heart, kidney, spleen and liver, the highest viral loads were found at $4 \mathrm{dpi}$, that is, only 1 day after the viremia peak, the maximum viral

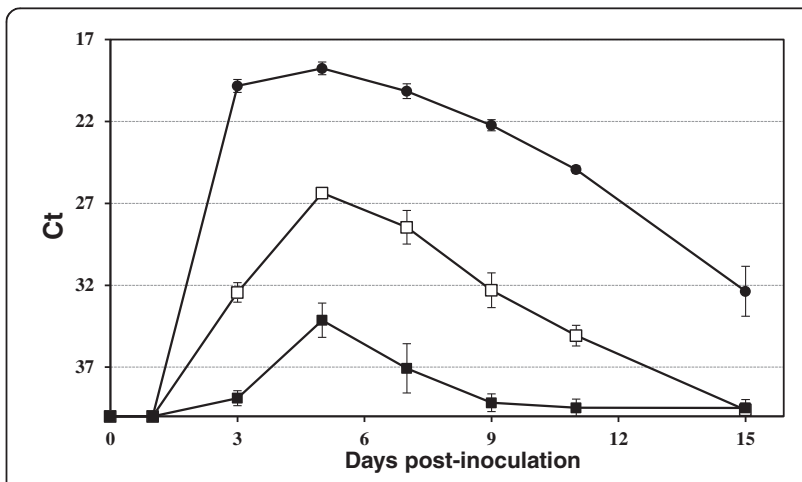

Figure $\mathbf{5}$ Viral genome load in swabs (oral, cloacal) and feathers from BAGV-inoculated red-legged partridges. The course of the viral RNA load in each type of sample, measured by real-time RT-PCR specific for BAGV, is represented on different days post-inoculation. Open squares indicate viral load in oral swabs; closed squares viral load in cloacal swabs and closed circles viral load in feathers. Error bars represent standard error of the mean. 
Table 2 BAGV detection by real time RT-PCR in organs from inoculated red-legged partridges

\begin{tabular}{llllllll}
\hline Partridge & Sex & dpi & \multicolumn{7}{l}{ Viral load in organs (Ct) } \\
\cline { 3 - 8 } & & & Brain & Heart & Kidney & Spleen & Liver \\
\hline N 1 & female & 4 & 29 & 19 & 21 & 21 & 21 \\
N 4 & male & 4 & 30 & 25 & 23 & 23 & 22 \\
$4^{*}$ & female & 6 & 27 & 23 & 23 & 23 & 24 \\
N 2 & female & 7 & 22 & 22 & 22 & 24 & 23 \\
N 5 & male & 7 & 27 & 23 & 25 & 27 & 30 \\
10* & male & 7 & 24 & 21 & 25 & 24 & 25 \\
N 3 & female & 10 & 30 & 29 & 27 & 32 & 31 \\
N 6 & male & 10 & 26 & 28 & 23 & 29 & 33 \\
$7^{*}$ & male & 10 & $21^{\dagger}$ & 26 & 25 & 28 & 33 \\
1 & male & 15 & 34 & $>40$ & 37 & 34 & $>40$ \\
2 & female & 15 & 31 & 32 & 31 & 29 & 37 \\
3 & female & 15 & 33 & 32 & 32 & 32 & 37 \\
5 & female & 15 & 31 & 32 & 32 & 31 & 34 \\
6 & male & 15 & 33 & 35 & 34 & 30 & 38 \\
8 & male & 15 & 31 & 32 & 30 & 30 & 38 \\
9 & male & 15 & 35 & 35 & 34 & 31 & 35 \\
\hline
\end{tabular}

Individual partridges are numbered correlatively ( $\mathrm{N}$ indicates partridges in the programmed necropsy group). The table indicates the sex of the sampled partridges, the day post infection (dpi) when the samples were obtained and the corresponding viral load expressed in Ct (threshold cycle) obtained by real-time RT-PCR analysis, for the different organs examined.

*Lethally infected birds; ${ }^{\dagger}$ Complete sequence analyzed.

load in the brain was observed 3-5 days later, that is, at 7-10 dpi. After that, over time, the viral genome load declined, but at day 15 post infection, the virus could still be detected in most organs (see Additional file 1).

One of the tissue samples examined (the brain from the necropsy of partridge 7 , which died at $10 \mathrm{dpi}$ ) which showed a high viral genome load $(\mathrm{Ct}=21)$ (Table 2) was chosen for further genetic characterization by complete sequence analysis. The sequence obtained (GenBank:KR108246), was identical to the complete sequence of the BAGV strain used for the inoculation (GenBank:KR108245).

\section{Contact transmission in red-legged partridges}

None of the four contact partridges died during the experiment. However, all of them showed viremia, viral shedding through the oral and cloacal routes and the presence of virus in feathers. Furthermore, three of them suffered important body weight loss and developed neutralizing antibodies. The presence of viral RNA was confirmed in all analyzed tissues at the end of the experiment (Table 3).

Three out of four contact partridges showed a delay of 5 to 9 days in the development of disease signs and evidence of infection (viral load, antibodies in serum and weight loss), as compared to inoculated birds (Table 3). In one of these contact partridges (contact 3), a viral load in oral swab was detected four days before it became viremic. In the fourth contact partridge, signs of the disease and evidence of infection appeared approximately 13 days later than in the inoculated group.

\section{Discussion}

To our knowledge, this study is the first one describing an experimental infection with BAGV in a European wild bird species, the red-legged partridge. In laboratorycontrolled conditions, the study demonstrated that this species is susceptible to BAGV infection and, as a consequence, develops a disease with signs compatible with those observed in field conditions in the outbreak in Cádiz, Spain, in 2010 [13]. Therefore, Bagaza virus was concluded to be the causative agent of this disease. The virus appeared to be rather stable as its complete genome sequence, obtained from the brain of one of the clinically affected partridges, was identical to the genome sequence of the virus strain used in the inoculum. In contrast, under the experimental conditions assayed, the virus affected neither house sparrows nor mice, which presumably reflects some sort of resistance to the infection in these species that can rely on their genetic background and/or innate immune mechanisms. A role for adaptive (humoral) immunity was specifically discarded, since all the animals were found to be negative for specific BAGV antibodies prior to inoculation.

In the outbreak in Southern Spain in 2010, BAGV not only affected red-legged partridges but also two other wild bird species: the common pheasant (Phasianus colchicus) and, to a lesser extent, the common wood pigeon (Columba palumbus) [13]. Other avian species, such as the domestic turkey (Melleagris gallipavo) or the Japanese quail (Coturnix coturnix), were proven susceptible to natural and experimental infection caused by old strains of the synonymous virus ITV $[16,22,23]$ whereas chickens (except one-day-old chicks), ducks and pigeons were not susceptible [23]. Therefore, the host range of BAGV seems to mainly include members of the Phasianidae family, comprising partridges, turkeys, pheasants, quails and chickens. This study further supports this host range, since red-legged partridges, but not house sparrows, where shown susceptible to the disease. It is worth noting that the BAGV host range differs in this regard from that of $\mathrm{WNV}$, which includes passerines like the house sparrow $[24,25]$.

Regarding mammals, suckling mice had been shown susceptible to infection and disease after experimental inoculation of an Indian BAGV strain using the Culex tritaniorhynchus mosquito as the vector [17]. Experiments performed with an old ITV strain (1960) showed that it could be transmitted (although at low rates) to 
Table 3 Summary of the main results obtained in contact partridges

\begin{tabular}{|c|c|c|c|c|c|c|c|c|c|c|c|c|c|c|c|c|c|c|c|c|}
\hline \multirow[b]{2}{*}{ dpi } & \multicolumn{5}{|c|}{ Contact 1} & \multicolumn{5}{|c|}{ Contact 2} & \multicolumn{5}{|c|}{ Contact 3} & \multicolumn{5}{|c|}{ Contact 4} \\
\hline & 7 & 9 & 11 & 15 & 18 & 7 & 9 & 11 & 15 & 18 & 7 & 9 & 11 & 15 & 18 & 7 & 9 & 11 & 15 & 18 \\
\hline$\%$ init. weight & 96 & 94 & 91 & 81 & 83 & 98 & 97 & 98 & 100 & 96 & 98 & 97 & 97 & 91 & 76 & 99 & 99 & 100 & 90 & 91 \\
\hline VNT titre & $<10$ & $<10$ & 20 & 640 & 320 & $<10$ & $<10$ & $<10$ & $<10$ & $<10$ & $<10$ & $<10$ & $<10$ & 80 & 320 & $<10$ & $<10$ & $<10$ & 160 & 320 \\
\hline VL blood (Ct) & 29 & 30 & 32 & 39 & 38 & $>40$ & $>40$ & $>40$ & 26 & 29 & $>40$ & $>40$ & 25 & 33 & 38 & $>40$ & 25 & 20 & 33 & 35 \\
\hline $\mathrm{VL}$ oral. $(\mathrm{Ct})$ & 37 & 28 & 24 & 29 & $>40$ & $>40$ & $>40$ & $>40$ & $>40$ & 25 & 33 & $>40$ & 33 & 28 & 31 & $>40$ & 33 & 28 & 28 & 36 \\
\hline VL cloacal (Ct) & $>40$ & $>40$ & $>40$ & $>40$ & $>40$ & $>40$ & $>40$ & $>40$ & $>40$ & 28 & $>40$ & $>40$ & $>40$ & 37 & $>40$ & $>40$ & $>40$ & 37 & $>40$ & 36 \\
\hline \multirow[t]{2}{*}{$V L$ feather $(C t)$} & 34 & 20 & 20 & 24 & 37 & $>40$ & $>40$ & $>40$ & 25 & 20 & $>40$ & $>40$ & 23 & 21 & 23 & $>40$ & 35 & 19 & 22 & 24 \\
\hline & \multicolumn{5}{|c|}{ Contact 1} & \multicolumn{5}{|c|}{ Contact 2} & \multicolumn{5}{|c|}{ Contact 3} & \multicolumn{5}{|c|}{ Contact 4} \\
\hline
\end{tabular}

VL in organs (18 dpi) brain heart kidney spleen liver brain heart kidney spleen liver brain heart kidney spleen liver brain heart kidney spleen liver

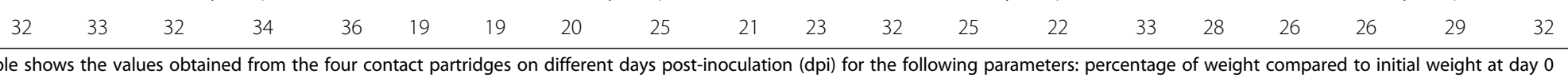

The upper part of the table shows (\% init. weight); neutralizing antibody titre in seum Ct values. The bottom part of the table shows the observed viral load (VL) measured by real-time RT-PCR (expressed in Ct values) in five different organs (the brain, heart, kidney, spleen and liver) at the time of necropsy of the contact partridges $(18 \mathrm{dpi})(\mathrm{neg}=\mathrm{Ct} \geq 40)$. 
suckling mice by $A$. aegyptii and Culex pipiens bites. In adult mice, ITV inoculation caused mortality when inoculated by intracerebral or intranasal routes but not when intraperitoneal or subcutaneous routes were used. This strain did not produce illness in adult hamsters or guinea pigs after intracranial inoculation [23,26]. In keeping with these previous observations, our results further suggested that BAGV has little effect, if any, on intraperitoneally inoculated adult mice.

Clinical signs observed in red-legged partridges during the experiment (weakness, reluctance to move, lack of avoidance to capture, and partially closed eyes) correlated well with neurologic signs and apparent blindness registered in natural infections $[13,14]$. However, the observations made under experimental conditions might not completely mimic what occurs in nature. The mortality rate in the inoculated partridges was $30 \%$, but morbidity reached $100 \%$, as all inoculated birds suffered significant weight loss. It is very likely that individuals that survived the experimental infection but suffered clinical illness would probably have died in the wild as a result of difficulties with feeding and/or escaping from predators. Viral pathogenicity evaluation in experimental trials is usually based on survival rates. Nevertheless, when experimental infections are performed in wild birds, the number of individuals is often limited due to animal welfare restrictions and logistic constraints derived from the wild origin of birds [27]. Consequently, statistically significant differences in mortality rates between groups are frequently difficult to observe. In this study, we evaluated not only mortality rates but also a morbidity index i.e. body weight loss, which proved to be a good indicator of disease severity and revealed dramatic differences between inoculated and control groups during the acute phase of the infection. This observation suggests that the accurate evaluation of quantitative indexes of morbidity, such as weight, can be useful to properly evaluate the pathogenicity of virus strains in an experimental setting.

Based on the data obtained on viremia, viral load in blood, oral and cloacal swabs, and feathers, the course of BAGV infection was similar to what has been described for the West Nile virus in partridges and corvids [28-30]. The delayed course of the viral load observed in the brain with respect to other peripheral organs suggested that crossing the blood-brain barrier is a late event during the infection. Persistent infections by other flaviviruses have been involved in alternative modes of transmission by predation of the affected avian hosts [31]. In our study, the BAGV genome was present in organs and feathers up to $15 \mathrm{dpi}$, but to properly assess this point, it would be necessary to carry out more prolonged experiments with higher number of birds. Despite similarities found in neutralizing antibody responses of red-legged partridges infected with BAGV and WNV [29], antibodies appeared slightly earlier (at $7 \mathrm{dpi}$ ) and reached higher titres at $15 \mathrm{dpi}$ of BAGV infection as compared to the WNV infection.

In this work, female partridges showed greater and more prolonged body weight loss after infection than males. A greater impact on female pheasants was also reported during the outbreak of BAGV in Spain, causing a reduction from 4 to 2.4 in the female/male ratio of hunted pheasants during the following hunting season [13]. Also in South Africa, a higher impact of illness in female turkeys was registered for the synonymous ITV [22]. However, the reason for this difference is still unclear.

BAGV-inoculated partridges showed a viremia peak higher than $10^{5} \mathrm{pfu} / \mathrm{mL}$. The viremia level necessary for BAGV infection of feeding mosquitoes has not been determined, but $10^{4}-10^{5} \mathrm{pfu} / \mathrm{mL}$ is the threshold of infectious viremia that has been experimentally established for other flaviviruses such as WNV to transmit the infection to Culex mosquitoes, one of its competent vectors [32,33]. If a similar threshold is assumed for BAGV, then the red-legged partridge could be considered a moderately competent host for BAGV transmission by mosquito bite, and therefore this species could play a role as a reservoir or amplifying host in nature. Viral shedding was higher and more consistent in oral secretions than in faeces, which is in accordance with the data obtained in field samples from partridges and pheasants during the BAGV outbreak [13]. Viral RNA was detected in feathers of infected birds at higher rates and for a longer period after infection in comparison with other samples (blood and swabs), so the feather could be a convenient sample to monitor virus circulation in surveillance programs, at least in red-legged partridges. A much greater viral load in growing feathers and with a longer persistence than in blood has also been found for Eastern equine encephalitis virus in ring-necked pheasants, avian leucosis virus in domestic chickens and West Nile virus in Gyr-Saker hybrid falcons $[34,35]$. Viral detection in vascular and non-vascular feathers of corvid carcasses has been proposed as useful for West Nile virus surveillance [34,36].

Interestingly, in this study, all contact-exposed birds became viremic and seroconverted, showing a high rate of contact transmission of BAGV in this host. In order to remove any potential ectoparasite present, all the individuals had been treated with pyrethroids before entering the experimental setting at the BSL3 facilities; consequently only direct transmission could explain the infection of contact individuals. In three out of four contact partridges, the signs of the disease started with a delay of 5 to 9 days with respect to syringeinoculated birds. The high amount of virus present in 
oral secretions and feathers of syringe-inoculated birds at that point suggests that the infection in contact-exposed birds was probably acquired through oral-oral route or by skin or feather picking. Viral detection in the oral swab in a contact partridge 4 days before viremia supports the idea of infection by the oral route. In the fourth contact partridge, the disease symptoms started 13 days later than in the syringe-inoculated partridges, suggesting that this partridge could have acquired the infection from the other contact birds in a second round of contact infection, and not from the inoculated group. This result contrasts with our previous observation that WNV was not transmitted to contact red-legged partridges under analogous experimental conditions [29]. Potential direct transmission of WNV has been assessed experimentally for at least 24 avian species [27], but contact transmission has only been demonstrated in five species belonging to three families: Common goose (Anser anser) [37], ring-billed gull (Larus delawarensis) and three species of corvids [33]. Nevertheless, the contact transmission rate observed in this work (4 out of 4 contact birds) for BAGV is considerably higher than that registered for WNV in any of the studied species.

Although contact transmission has been proposed to explain the rapid dissemination of ITV strains in turkey farms [22], this could not be proved in experimental trials and intranasal infection attempts in turkeys were also unsuccessful [16]. The high transmission rate observed in the present study suggests that partridges are highly competent hosts for BAGV contact transmission, and, at least in this avian species, this transmission route can be epidemiologically relevant. The red-legged partridge is one of the most important small game bird species in Southern Europe and the UK, where restocking of farmbred birds for hunting purposes is common. In breeding farms and, to a lesser extent, in the hunting properties where game birds aggregate in high densities around artificial feeders and water points, transmission risk by direct contact through water/food contamination or feather picking could be high.

The fact that BAGV has appeared in Southern Europe just once indicates that its introduction in this continent is a very unusual event. The BAGV geographic range includes Sub-Saharan Africa, and consequently, this area could be a possible origin for the introduction of BAGV into Spain. This hypothesis, however, needs to be substantiated, for instance, with sequence data recent African BAGV strains, but also with a suitable mechanism of introduction. Viraemic migratory birds or wind-borne infected mosquitoes have been proposed as mechanisms mediating the introduction of other flaviviruses $[38,39]$. Nevertheless, other alternative explanations like poultry industry-driven movements or trading of exotic birds should not be disregarded. Evidence of
BAGV circulation in Southern Spain in two consecutive seasons [6] supports the possibility of overwintering after the introduction of the virus and indicates a risk of expansion in areas with similar climate conditions and/or similar game bird release programs. Other epornitic arboviruses, such as WNV and USUV have spread slowly but relentlessly throughout large parts of Europe [1-4]. BAGV is likely to have a similar potential for dissemination, but displaying a more efficient contact transmission, at least in red-legged partridges, a characteristic that might cause large outbreaks in dense populations of susceptible birds, such as in farmed game birds, which could facilitate the adaptation and maintenance of the BAGV life cycle after a new introduction of the virus, and eventually the spread of this pathogen when game birds are released into the wild. Thus, epidemiological surveillance in these susceptible birds is needed in order to avoid the introduction, maintenance and spread of the disease.

In other European countries, other birds from the Phasianidae family (grey partridges, pheasants) play the same role for game as the red-legged partridge, being bred in captivity and released into the wild for hunting purposes. Consequently, susceptibility studies on these species are necessary to estimate to what extent the emergence of BAGV could affect game birds on the continent.

The emergence of BAGV in Spain has had dramatic consequences on game bird populations, in which it has caused high mortality rates, mainly in the red-legged partridge [5], a species with great economic and ecological value in Europe. Besides its economic importance, the risk of BAGV for public health is still unknown. On the one hand, its synonymous virus, ITV, has never been reported to cause illness in humans, despite circulating in turkeys in Israel for decades [23,40]; and on the other hand, the presence of neutralizing $\mathrm{Ab}$ against BAGV in humans with encephalitis suggests infection but not necessarily pathogenicity [11].

In summary, this study confirms that the red-legged partridge is susceptible to BAGV infection and disease, and can be a competent host for both mosquito and direct (contact) transmission. Consequently, the red-legged partridge constitutes a suitable target species for BAGV surveillance. Finally, feather sampling could be a useful strategy in active surveillance programs for early detection of BAGV.

\section{Additional file}

Additional file 1: BAGV RNA load in organs from inoculated red-legged partridges. Viral RNA load, expressed as threshold value $(\mathrm{Ct})$ was measured in five different organs (the heart, spleen, kidney, brain and liver) of BAGV-inoculated red-legged partridges. Closed circles indicate viral load in partridges of the programmed necropsy group and open circles show viral load in lethally infected partridges. A solid line represents the mean of the data of viral load at different days post-infection. 


\section{Competing interests}

The authors declare that they have no competing interests.

\section{Authors' contributions}

FL: prepared the inocula, carried out experimental infections, the clinical and analytical follow-ups, the analysis of clinical samples and the interpretation of the results, and drafted the manuscript; EP-R: prepared the inocula and carried out the experimental infections, the clinical and analytical follow-ups, the analysis of clinical samples and the interpretation of the results, and contributed to the drafting of the manuscript; JF-P and ME: carried out sequencing of the viral isolate; JF: captured and cared for the house sparrows used in the experiment before inoculation, and collaborated in the study design, the statistical analyses and the interpretation of the results; RCS: captured and cared for the house sparrows used in the experiment before inoculation, collaborated in the design of the study and interpretation of the results; MAJ-C: designed and coordinated the study, participated in the experimental infections and interpretation of the results, and contributed to the drafting of the manuscript. All the authors read and approved the final manuscript.

\section{Acknowledgements}

We would like to thank Lugar Nuevo red-legged partridge breeding facility (Estación de Referencia de la Perdiz Roja, Andújar-Jaén, Consejería de Medio Ambiente y Ordenación del Territorio, Junta de Andalucía) for providing the partridges used in this study. We are also grateful to the personnel from Doñana Biological Station who were involved in the capture and acclimatization of the house sparrows used in the experiments, and to the staff at INIA-CISA BSL-3 animal facilities where the experiments were carried out. This study was funded by National grant AGL2011-13634-E, European Commission grant HEALTH.2010.2.3-3-3 Project 261391 EuroWestNile and PAIDI RNM118.

\section{Author details}

${ }^{1}$ Centro de Investigación en Sanidad Animal, Instituto Nacional de Investigación y Tecnología Agraria y Alimentaria (INIA-CISA), Ctra Algete-El Casar s/n, Valdeolmos, Spain. ²Estación Biológica de Doñana (EBD-CSIC), Avenida de Americo Vespucio s/n, Seville, Spain.

\section{Received: 6 May 2015 Accepted: 31 July 2015}

\section{Published online: 04 September 2015}

\section{References}

1. Weissenböck H, Hubálek Z, Bakonyi T, Nowotny N (2010) Zoonotic mosquito-borne flaviviruses: worldwide presence of agents with proven pathogenicity and potential candidates of future emerging diseases. Vet Microbiol 140:271-280

2. Vazquez A, Jimenez-Clavero MA, Franco L, Donoso-Mantke O, Sambri V, Niedrig M, Zeller H, Tenorio A (2011) Usutu virus: potential risk of human disease in Europe. Euro Surveill 16:19935

3. Beck C, Jimenez-Clavero MA, Leblond A, Durand B, Nowotny N, Leparc-Goffart I, Zientara S, Jourdain E, Lecollinet S (2013) Flaviviruses in europe: complex circulation patterns and their consequences for the diagnosis and control of west nile disease. Int J Environ Res Public Health 10:6049-6083

4. Rizzoli A, Jimenez-Clavero M, Barzon L, Cordioli P, Figuerola J, Koraka P, Martina B, Moreno A, Nowotny N, Pardigon N, Sanders N, Ulbert S, Tenorio A (2015) The challenge of West Nile virus in Europe : knowledge gaps and research priorities. Euro Surveill 20:21135

5. Agüero $M$, Fernandez-Pinero J, Buitrago D, Sanchez A, Elizalde M, San Miguel E, Villalba R, Llorente F, Jimenez-Clavero MA (2011) Bagaza virus in partridges and pheasants, Spain, 2010. Emerg Infect Dis 17:1498-1501

6. Llorente F, Perez-Ramirez E, Fernández-Pinero J, Soriguer R, Figuerola J, Jiménez-Clavero MA (2013) Flaviviruses in Game Birds, Southern Spain, 2011-2012. Emerg Infect Dis 19:1023-1025

7. Digoutte JP (1978) Bagaza (BAG) strain Dak Ar B 209. Am J or Trop Med Hyg 27:376-377

8. Diallo M, Nabeth $\mathrm{P}, \mathrm{Ba}$ K, Sall AA, Ba Y, Mondo M, Girault L, Abdalahi MO, Mathiot C (2005) Mosquito vectors of the 1998-1999 outbreak of Rift Valley Fever and other arboviruses (Bagaza, Sanar, Wesselsbron and West Nile) in Mauritania and Senegal. Med Vet Entomol 19:119-126
9. Gordon SW, Tammariello RF, Linthicum KJ, Dohm DJ, Digoutte JP, Calvo-Wilson MA (1992) Arbovirus isolations from mosquitoes collected during 1988 in the Senegal River basin. Am J Trop Med Hyg 47:742-748

10. Traore-Lamizana M, Zeller HG, Mondo M, Hervy JP, Adam F, Digoutte JP (1994) Isolations of West Nile and Bagaza viruses from mosquitoes (Diptera: Culicidae) in central Senegal (Ferlo). J Med Entomol 31:934-938

11. Bondre VP, Sapkal GN, Yergolkar PN, Fulmali PV, Sankararaman V, Ayachit VM, Mishra AC, Gore MM (2009) Genetic characterization of Bagaza virus (BAGV) isolated in India and evidence of anti-BAGV antibodies in sera collected from encephalitis patients. J Gen Virol 90:2644-2649

12. Fernandez-Pinero J, Davidson I, Elizalde M, Perk S, Khinich $Y$, Jimenez-Clavero MA (2014) Bagaza virus and Israel turkey meningoencephalomyelitis virus are a single virus species. J Gen Virol 95:883-887

13. Gamino V, Gutiérrez-Guzmán AV, Fernández-de-Mera IG, Ortíz J-A, Durán-Martín M, de la Fuente J, Gortázar C, Höfle U (2012) Natural Bagaza virus infection in game birds in southern Spain. Vet Res 43:65

14. Gamino V, Escribano-Romero E, Gutiérrez-Guzmán AV, Blázquez AB, Saiz JC, Höfle U (2014) Oculopathologic findings in flavivirus-infected gallinaceous birds. Vet Pathol 51:1113-1116

15. García-Bocanegra I, Zorrilla I, Rodríguez E, Rayas E, Camacho L, Redondo I, Gómez-Guillamón F (2012) Monitoring of the Bagaza Virus epidemic in wild bird species in Spain, 2010. Transbound Emerg Dis 59:448-455

16. lanconescu M, Aharonovici A, Samberg Y, Hornstein K, Merdinger M (1973) Turkey meningo-encephalitis: pathogenic and immunological aspects of the infection. Avian Pathol 2:251-262

17. Sudeep AB, Bondre VP, Mavale MS, Ghodke YS, George RP, Aher RV, Gokhale MD (2013) Preliminary findings on Bagaza virus (Flavivirus: Flaviviridae) growth kinetics, transmission potential \& transovarial transmission in three species of mosquitoes. Indian J Med Res 138:257-261

18. Payne AF, Binduga-Gajewska I, Kauffman EB, Kramer LD (2006) Quantitation of flaviviruses by fluorescent focus assay. J Virol Methods 134:183-189

19. Buitrago $D$, Rocha A, Tena-Tomás C, Vigo M, Agüero M, Jiménez-Clavero MA (2012) Real-time fluorogenic reverse transcription polymerase chain reaction assay for the specific detection of Bagaza virus. J Vet Diagn Invest 24:959-963

20. Figuerola J, Jiménez-Clavero MA, Rojo G, Gómez-Tejedor C, Soriguer R (2007) Prevalence of West Nile virus neutralizing antibodies in colonial aquatic birds in southern Spain. Avian Pathol 36:209-212

21. Gehan EA (1965) A generalized Wilcoxon test for comparing arbitrarily singly-censored samples. Biometrika 52:203-223

22. Barnard BJ, Buys SB, Du Preez JH, Greyling SP, Venter HJ (1980) Turkey meningo-encephalitis in South Africa. Onderstepoort J Vet Res 47:89-94

23. Komarov A, Kalmar E (1960) A hitherto undescribed disease-turkey meningo-encephalitis. Vet Rec 72:257-261

24. Del Amo J, Llorente F, Pérez-Ramirez E, Soriguer RC, Figuerola J, Nowotny N, Jiménez-Clavero MA (2014) Experimental infection of house sparrows (Passer domesticus) with West Nile virus strains of lineages 1 and 2. Vet Microbiol 172:542-547

25. Del Amo J, Llorente F, Figuerola J, Soriguer RC, Moreno AM, Cordioli P, Weissenböck H, Jiménez-Clavero MA (2014) Experimental infection of house sparrows (Passer domesticus) with West Nile virus isolates of Euro-Mediterranean and North American origins. Vet Res 45:33

26. Nir Y (1972) Some characteristics of Israel turkey virus. Arch Gesamte Virusforsch 36:105-114

27. Pérez-Ramírez E, Llorente F, Jiménez-Clavero MA (2014) Experimental infections of wild birds with West Nile virus. Viruses 6:752-781

28. Dridi M, Vangeluwe D, Lecollinet S, van den Berg T, Lambrecht B (2013) Experimental infection of Carrion crows (Corvus corone) with two European West Nile virus (WNV) strains. Vet Microbiol 165:160-166

29. Sotelo E, Gutierrez-Guzmán AV, Del Amo J, Llorente F, El-Harrak M, Pérez-Ramírez E, Blanco JM, Höfle U, Jiménez-Clavero MÁ (2011) Pathogenicity of two recent Western Mediterranean West Nile virus isolates in a wild bird species indigenous to Southern Europe: the red-legged partridge. Vet Res 42:11

30. Suthar MS, Diamond MS, Gale M (2013) West Nile virus infection and immunity. Nat Rev Microbiol 11:115-128

31. Nemeth N, Young G, Ndaluka C, Bielefeldt-Ohmann H, Komar N, Bowen R (2009) Persistent West Nile virus infection in the house sparrow (Passer domesticus). Arch Virol 154:783-789

32. Turell MJ, O'Guinn M, Oliver J (2000) Potential for New York mosquitoes to transmit West Nile virus. Am J Trop Med Hyg 62:413-414 
33. Komar N, Langevin S, Hinten S, Nemeth N, Edwards E, Hettler D, Davis B, Bowen R, Bunning M (2003) Experimental infection of North American birds with the New York 1999 strain of West Nile virus. Emerg Infect Dis 9:311-322

34. Docherty D, Long R (2004) Corvidae feather pulp and West Nile virus detection. Emerg Infect Dis 10:907-909

35. Busquets N, Bertran $K$, Costa TP, Rivas R, de la Fuente JG, Villalba R, Solanes D, Bensaid A, Majó N, Pagès N (2012) Experimental West Nile virus infection in Gyr-Saker hybrid falcons. Vector Borne Zoonotic Dis 12:482-489

36. Nemeth NM, Young GR, Burkhalter KL, Brault AC, Reisen WK, Komar N (2009) West Nile virus detection in nonvascular feathers from avian carcasses. J Vet Diagn Invest 21:616-622

37. Banet-Noach C, Simanov L, Malkinson M (2003) Direct (non-vector) transmission of West Nile virus in geese. Avian Pathol 32:489-894

38. Mackenzie JS, Gubler DJ, Petersen LR (2004) Emerging flaviviruses: the spread and resurgence of Japanese encephalitis, West Nile and dengue viruses. Nat Med 10(12 Suppl):S98-S109

39. López G, Jiménez-Clavero MA, Tejedor CG, Soriquer R, Figuerola J (2008) Prevalence of West Nile virus neutralizing antibodies in Spain is related to the behavior of migratory birds. Vector Borne Zoonotic Dis 8:1-5

40. Braverman Y, Davidson I, Chizov-Ginzburg A, Chastel C (2003) Detection of Israel turkey meningo-encephalitis virus from mosquito (Diptera: Culicidae) and Culicoides (Diptera: Ceratopogonidae) species and its survival in Culex pipiens and Phlebotomus papatasi (Diptera: Phlebotomidae). J Med Entomol 40:518-521

\section{Submit your next manuscript to BioMed Central and take full advantage of:}

- Convenient online submission

- Thorough peer review

- No space constraints or color figure charges

- Immediate publication on acceptance

- Inclusion in PubMed, CAS, Scopus and Google Scholar

- Research which is freely available for redistribution 